\title{
Skin Pass Rolling of High Manganese Steels
} Kai Köhler ${ }^{1, a}$, Norbert Kwiaton ${ }^{1, b}$ and Martin Bretschneider ${ }^{1, c}$

\author{
${ }^{1}$ Salzgitter Mannesmann Forschung GmbH, Eisenhüttenstraße 99, 38239 Salzgitter, Germany \\ ak.koehler@sz.szmf.de, bn.kwiaton@sz.szmf.de, ${ }^{\mathrm{c} m}$.bretschneider@sz.szmf.de
}

Keywords: skin pass rolling, high manganese steel, roughness characteristics, $\mathrm{HSD}^{\circledR}, \mathrm{PRETEX}^{\circledR}$, work-roll texturing.

\begin{abstract}
Applying a specific roughness on steel sheets, to ensure paintability and sufficient lubrication, is a crucial point for the metal forming processes. Due to the strength of high manganese HSD $^{\circledR}$ steels (X70MnAlSi 15-2.5-2.5), special actions are necessary to obtain the required roughness. At Salzgitter Mannesmann Forschung GmbH skin pass rolling experiments on high manganese HSD $^{\circledR}$ steels with different PRETEX ${ }^{\mathbb{R}}$ textured work-rolls were performed to investigate the influence of roll-surface-texture and skin pass rolling force on the roughness transfer. The roughness and texture parameters of the steel sheets and roll surfaces were determined using optical confocal microscopy measurements. It is clearly shown that the work-roll surface texture has a major influence on the roughness transfer from work-rolls to steel sheet surfaces.
\end{abstract}

\section{Introduction}

Different work-roll surface texturing methods are industrially used i.e. electron discharge texturing (EDT), laser and electron beam texturing (LBT, EBT), shot blast texturing (SBT) and Topocrom $^{\circledR}$ (also called electro-chrome deposition (ECD)) [1-3]. The work-rolls used in the present investigations were textured using the galvanic Topocrom ${ }^{\circledR}$ technique (see Fig. 1).

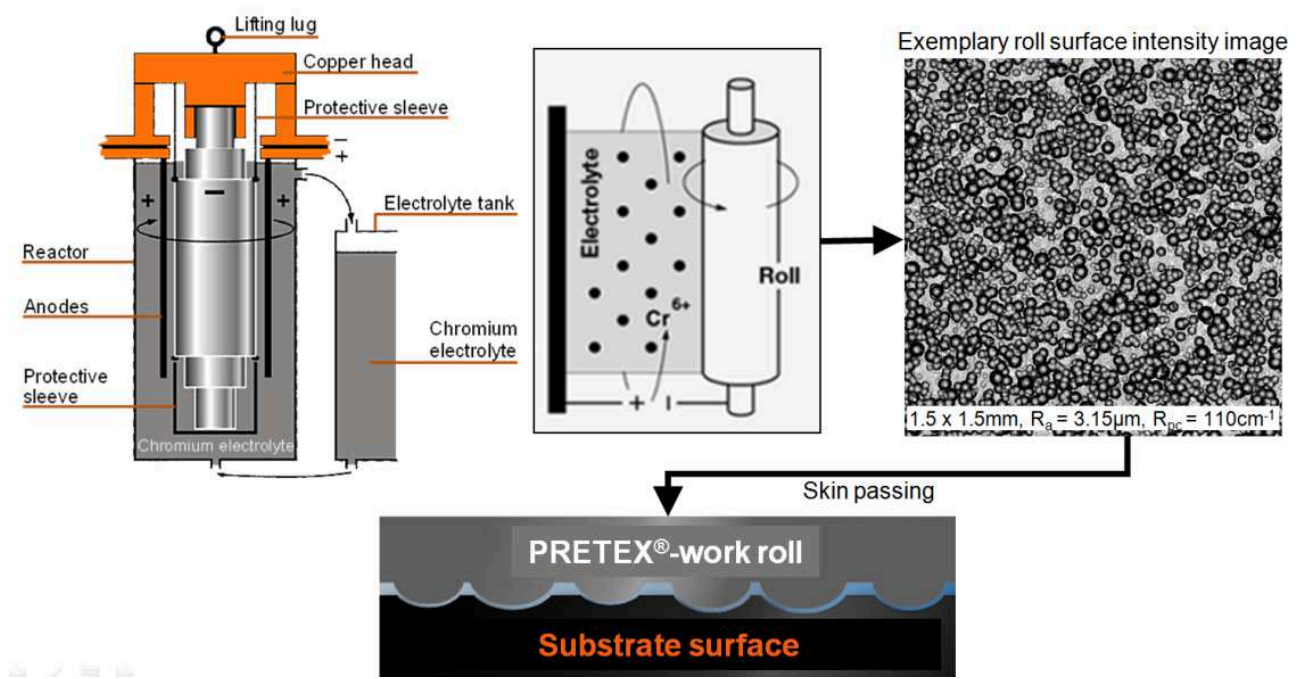

Fig. 1: Schematic sketch of the Topocrom ${ }^{\circledR}$ roll plating process and the principle of texture transfer from roll to steel sheet surface during skin passing. Chromium is electrolytically deposited on roll surfaces where it forms the characteristic half dome calottes of the PRETEX ${ }^{\circledR}$ roll surface.

The transfer of the specific topographies from roll to steel sheet surfaces is realized through skin passing [4]. Skin passing or temper rolling is the deformation of steel strips with small plastic deformations between approximately 0.1 to $2 \%$. The actual sheet roughness depends on a variety of parameters, e.g. the material dimensions, strength and strain hardening coefficients, the work-roll diameter and surface texture and especially the rolling forces. Recent literature on roughness transfer in skin pass rolling mainly deals with electron discharge textured rolls and carbon steel as sample material [5-11]. In contrast, the present investigation uses a Topocrom ${ }^{\circledR}$ textured roll set to 
transfer roughness to $\mathrm{HSD}^{\circledR}$ steel, a high manganese second generation advanced high strength steel.

\section{Roughness Characteristics}

To characterize the surface roughness well-established and standardized parameters such as average roughness $\left(R_{a}, S_{a}\right)$ and peak count $\left(R_{P c}\right)$ as well as the self-developed and not standardized characteristic calotte density $\left(C_{d}\right)$ were used [12]. $R_{a}$ and $R_{P c}$ were determined with tactile measurements, $S_{a}$ and $C_{d}$ by means of optical confocal microscopy measurements.

In Fig. 2 textures of three roll surfaces are shown, each having an average roughness $\left(R_{a}\right)$ of $2.7 \mu \mathrm{m}$ and a peak count $\left(\mathrm{R}_{\mathrm{pc}}\right)$ of $107 \mathrm{~cm}^{-1}$. As it is clearly visible, the surfaces differ significantly in the number of calottes per unit area, which can be expressed with the calotte density $\mathrm{C}_{\mathrm{d}}$ (calottes per $\mathrm{mm}^{2}$ ). This means that the same set of work-roll roughness parameters $R_{a}$ and $R_{p c}$ can be achieved while having different calotte densities. Surfaces bearing low densities of calottes (Fig. 2 a)) are denoted as "open structure", whereas surfaces with high densities of calottes (Fig. 2 b)) are denoted as "closed structure".

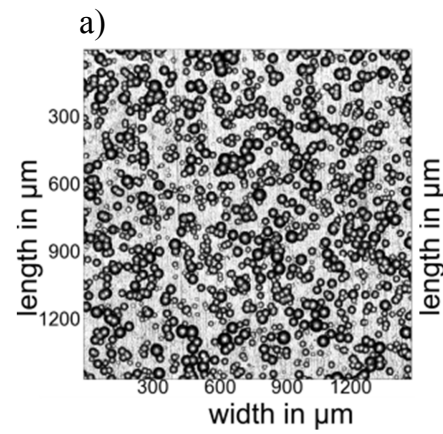

b)

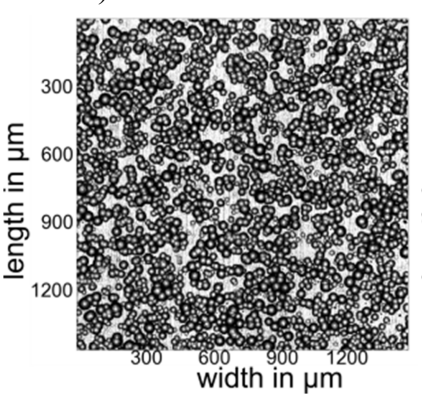

c)

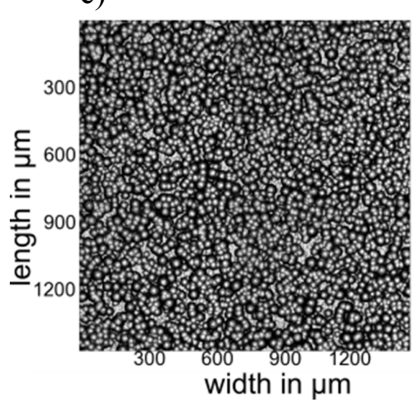

Fig. 2: Intensity images of white light microscopy of three different roll textures with the same $2 \mathrm{~d}$ roughness values $R_{a}=2.7 \mu \mathrm{m}$ and $R_{p c}=107 \mathrm{~cm}^{-1}$ but different calotte densities. a) $C_{d}=241 \mathrm{~mm}^{-2}$, b) $\mathrm{C}_{\mathrm{d}}=297 \mathrm{~mm}^{-2}$, c) $\mathrm{C}_{\mathrm{d}}=370 \mathrm{~mm}^{-2}$

\section{Measurement Technique}

The surfaces of the skin pass rolls and steel sheet samples were measured automatically. Therefore, roll surface replicas were taken and then inspected with the 3-dimensional roughness measurement device surf mobile from the company Nanofocus, which is based on confocal microscope [13]. The confocal microscope is used only to generate the intensity and roughness image raw data that are later processed with a series of self developed analysis algorithms based on the open source software GNU Octave. This architecture allows easy modifications on the post processing side, when needed, without having to repeat the measurements. The raw data are automatically collected from the measurement device and then processed to calculate several surface topography characteristics (see below), plotted and saved into a database. A selection of the calculated roughness parameters is given in the following list:

- $\mathbf{S}_{\mathbf{a}}$ (surface average) is the $2 \mathrm{~d}$ roughness value $\mathrm{R}_{\mathrm{a}}$ brought into $3 \mathrm{~d}$ measurement. It is the mean roughness calculated from all the measurement pixels. The higher $S_{a}$, the rougher the surface.

- $\mathbf{C}_{\mathbf{d}}$ (calottes density) is the number of calottes in a $1 \times 1 \mathrm{~mm}^{2}$ measuring field. The higher $\mathrm{C}_{\mathbf{d}}$ gets, the more calottes exist.

The $C_{d}$ characteristic is computed using the Hough transform image analysis method. The Hough transform has the ability to find similar features in images, basically simple features like lines. However the Hough transform can also be modified to search for more complex features [14]; in this case, the method detects the calottes that always have a circular shape. This robust method also has the advantage that it only needs some parts of the object to be found, which is necessary since the calottes can overlap or be right next to each other with no sharp border between them. 


\section{Material}

The sample materials used in this investigation and their mechanical properties are given in Table 1. The micro-alloyed steel HC340LA was supplied as a well deformable, lower strength reference material.

Table 1: Sample materials used in this investigation. $\mathrm{R}_{\mathrm{p} 0,2} / \mathrm{R}_{\mathrm{el}}=$ yield strength, $\mathrm{R}_{\mathrm{m}}=$ tensile strength, $\mathrm{A}_{80}=$ elongation at fracture, $\mathrm{n}$-value $=$ strain hardening coefficient

\begin{tabular}{rcccc}
\hline & HSD $^{\circledR} \mathbf{6 0 0}$ & HSD $^{\circledR} \mathbf{9 0 0}$ & HSD $^{\circledR} \mathbf{1 1 0 0}$ & $\begin{array}{c}\text { HC340LA } \\
\mathbf{1 . 0 5 4 8}\end{array}$ \\
\hline $\mathrm{R}_{\mathrm{p} 0,2}[\mathrm{MPa}]$ & 620 & 920 & 1100 & - \\
$\mathrm{R}_{\mathrm{el}}[\mathrm{MPa}]$ & - & - & - & 360 \\
$\mathrm{R}_{\mathrm{m}}[\mathrm{MPa}]$ & 1000 & 1150 & 1250 & 423 \\
$\mathrm{~A}_{80}[\%]$ & 50 & 30 & 17 & 30 \\
$\mathrm{n}-\mathrm{value}$ & 0.36 & 0.19 & - & 0.19 \\
thickness $[\mathrm{mm}]$ & 1.3 & 1.3 & 1.3 & 1.4 \\
Sheet roughness & 0.18 & 0.15 & 0.24 & 0.14 \\
$\mathrm{~S}_{\mathrm{a}}[\mu \mathrm{m}]$ & & & &
\end{tabular}

In all experiments sheet material with a width of $250 \mathrm{~mm}$ and a length of $1000 \mathrm{~mm}$ was used and no lubricants were applied.

\section{Laboratory Rolling Mill}

All experiments were carried out on the laboratory cold rolling mill at Salzgitter Mannesmann Forschung GmbH in Salzgitter. The rolling forces of the $250 \mathrm{~mm}$ wide $\mathrm{HSD}^{\circledR}$ sheets were between $300 \mathrm{kN}$ and $2400 \mathrm{kN}$ and were kept constant during each skin pass rolling trial. However, in further discussions the normalized specific rolling force (force per meter sheet width) will be used. Technical details of the laboratory cold rolling mill are given in Table 2.

Table 2: Technical details of the laboratory cold rolling mill

\begin{tabular}{cccc}
\hline roll diameter $[\mathrm{mm}]$ & sheet width $[\mathrm{mm}]$ & sheet speed $[\mathrm{m} / \mathrm{min}]$ & max. rolling force $[\mathrm{kN}]$ \\
\hline $330-360$ & $100-300$ & $\begin{array}{c}\text { used: } 6 \\
\text { max: } 60\end{array}$ & 5500 \\
\hline
\end{tabular}

The PRETEX ${ }^{\circledR}$ texturing of the work-roll pair was carried out at the company TOPOCROM ${ }^{\circledR}$ (see Fig. 1). Both rolls were coated with the same average roughness $S_{a}$ but with different calotte densities, which resulted in one roll having an open and one roll having a closed PRETEX ${ }^{\circledR}$ surface structure (see Fig. 2). The roughness parameters of both rolls are given in Table 3.

Table 3: Work-roll roughness parameters: $S_{a}=$ average roughness, $C_{d}=$ calotte density

\begin{tabular}{ccc}
\hline $\begin{array}{c}\text { surface } \\
\text { structure type }\end{array}$ & $\mathrm{S}_{\mathrm{a}}[\mu \mathrm{m}]$ & $\mathrm{C}_{\mathrm{d}}\left[\mathrm{mm}^{-1}\right]$ \\
\hline open & 3.3 & 220 \\
closed & 3.3 & 290 \\
\hline
\end{tabular}




\section{Experimental Results}

In this study, skin pass rolling experiments on high manganese $\mathrm{HSD}^{\circledR}$ steels with different PRETEX $^{\circledR}$ textured work-rolls were performed to investigate the texture and rolling force influence on the roughness transfer. The texture was altered so that the work-rolls had the same average roughness $S_{a}$ but different calotte densities $C_{d}$. Through this, open and closed PRETEX ${ }^{\circledR}$ structures were formed on the work-roll surfaces (see Fig. 2 and Table 3). The results of the skin pass experiments are summarized in Figs. 3 and 4. In these figures the average sheet roughness $S_{a}$ and the roughness transfer from work-rolls to sheet surfaces are given as a function of the applied specific roll forces (force per meter sheet width).

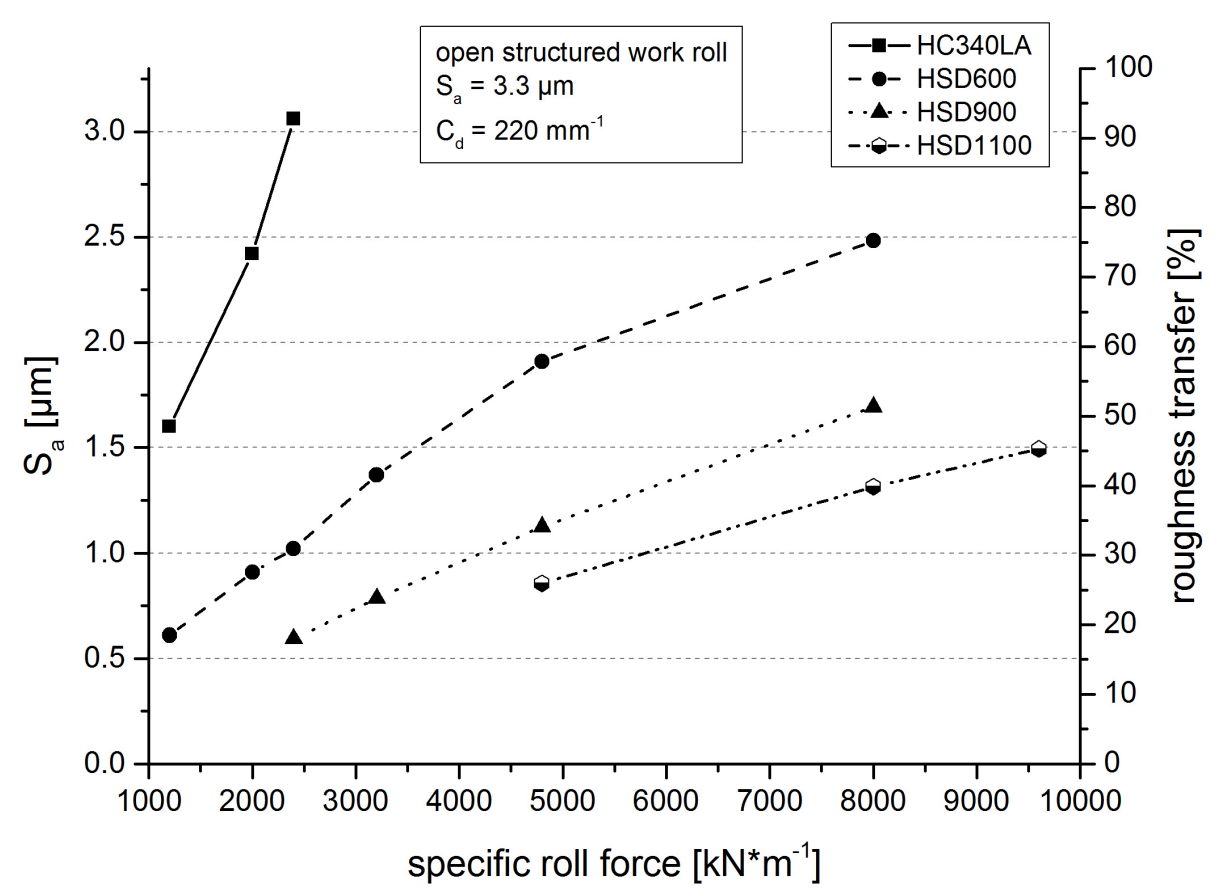

Fig. 3: Results of skin pass rolling experiments using a work-roll having an open surface structure with a calotte density $C_{d}$ of $220 \mathrm{~mm}^{-1}$. The average roughness $S_{a}$ and the roughness transfer as a function of the specific roll forces are shown.

Figs. 3 and 4 show, particularly for the set of $\mathrm{HSD}^{\circledR}$ steels, that the roughness transfer at a given rolling force decreases with increasing yield strength. This is true for both open and closed PRETEX $^{\circledR}$ textured work-rolls. As an example, the average roughness and the roughness transfer at a specific rolling force of $4800 \mathrm{kN} / \mathrm{m}$ for the open structured roll will be considered. Using this rolling force, roughness transfers of about $60 \%$ for $\operatorname{HSD}^{\circledR} 600,35 \%$ for $\operatorname{HSD}^{\circledR} 900$ and $27 \%$ for $\mathrm{HSD}^{\mathbb{R}} 1100$ were achieved, resulting in an average roughness of $1.9 \mu \mathrm{m}, 1.1 \mu \mathrm{m}$ and $0.9 \mu \mathrm{m}$, respectively. Depending on the specific roll force, the overall applied average roughness $\mathrm{S}_{\mathrm{a}}$ for HSD steels varied between $0.6 \mu \mathrm{m}$ and $2.5 \mu \mathrm{m}$ for the open structured work-roll and between $0.4 \mu \mathrm{m}$ and $1.9 \mu \mathrm{m}$ for the closed structured work-roll.

The major goal of the present skin pass rolling trials was to investigate the influence of the workroll PRETEX ${ }^{\mathbb{B}}$ texture on the roughness transfer to high manganese steels. A comparison of the roughness transfer values in Figs. 3 and 4 show that the open structured work-roll does in all cases transfer a higher ratio of its roughness to steel sheet surfaces.

A numerical comparison is listed in Table 4, where the ratios of roughness transfer values for the open and closed structured work-rolls were calculated as a function of the specific rolling forces. For example transfers the open structured work roll $35.6 \%$ of its roughness to a $\mathrm{HSD}^{\circledR} 900$ steel sheet at a specific rolling force of $4800 \mathrm{kN} / \mathrm{m}$, whereas the closed structured roll transfers $19.6 \%$ (see Figs. 3 and 4). The ratio of these roughness transfer values is $35.6 \% / 19.6 \%=1.82$ which is 
equivalent to an increased roughness transfer of $82 \%$ for the open structured work roll (assuming that the transfer value for the closed structured roll corresponds to $100 \%$ ).

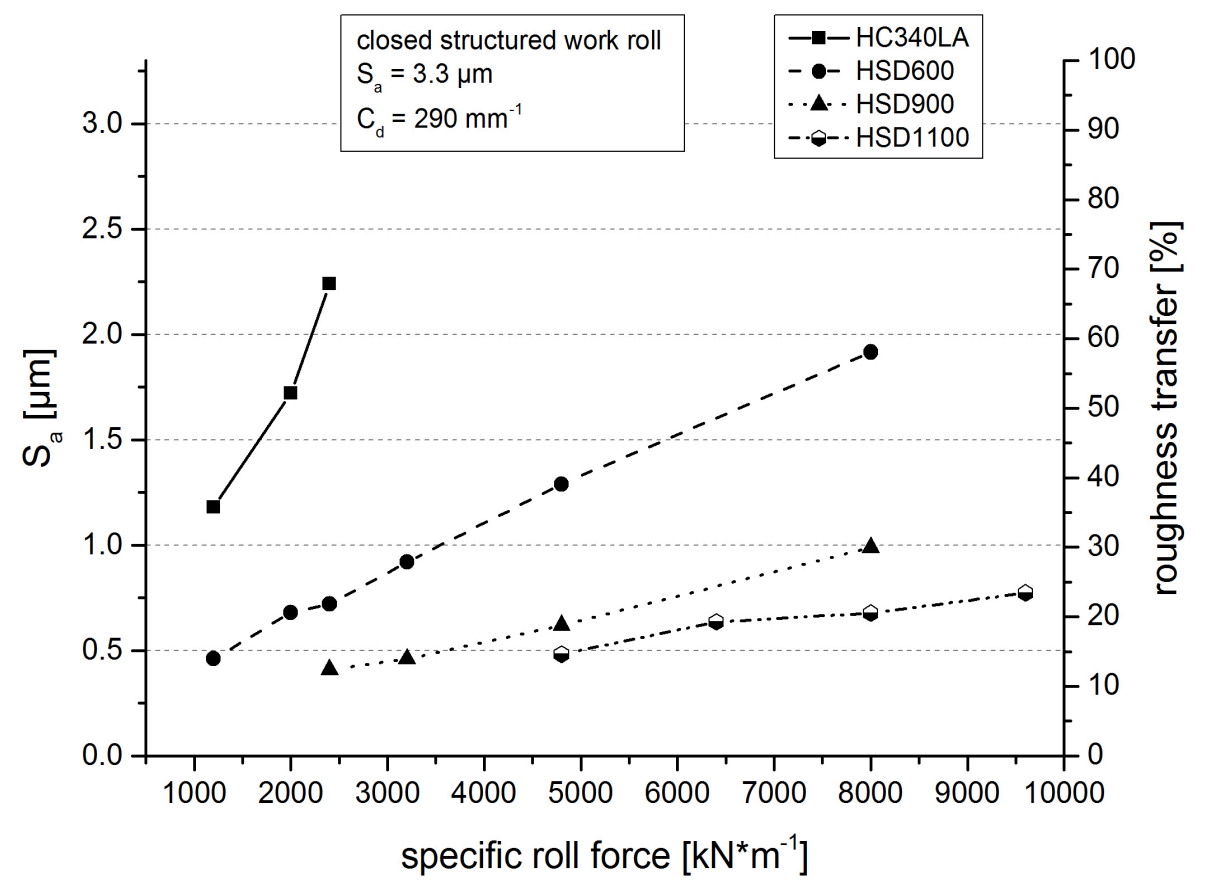

Fig. 4: Results of skin pass rolling experiments using a work-roll having a closed surface structure with a calotte density $C_{d}$ of $290 \mathrm{~mm}^{-1}$. The average roughness $S_{a}$ and the roughness transfer as a function of the specific roll forces are shown.

The calculations show that increases in roughness transfer up to $94 \%$ were achieved when shifting from a closed structured work-roll to an opened structured one. The higher transfer values can be attributed to the fact that open structured rolls have fewer calottes on their surfaces which leads to higher specific forces per calotte during skin passing compared to closed structured rolls.

Table 4: Ratios of roughness transfer values of open and closed structured work-rolls as a function of the specific roll forces (see Figs. 3 and 4). In all cases, open structured rolls transfer more of their roughness to steel sheets surfaces. See text for explanation.

\begin{tabular}{|c|c|c|c|c|}
\hline \multirow[b]{2}{*}{$\begin{array}{c}\text { specific roll } \\
\text { force }\left[\mathbf{k} \mathbf{N}^{*} \mathbf{m}^{-1}\right]\end{array}$} & \multicolumn{4}{|c|}{ ratios of roughness transfer values for (open /closed) work-roll structures } \\
\hline & HC340LA & HSD $^{\circledR} 600$ & HSD $^{\circledR} 900$ & HSD $^{\circledR} 1100$ \\
\hline 1200 & $\begin{array}{l}1.36 \\
(47.8 \% / 35.1 \%)\end{array}$ & $\begin{array}{l}1.33 \\
(18.3 \% / 13.8 \%)\end{array}$ & & \\
\hline 2000 & $\begin{array}{l}1.42 \\
(72.6 \% / 51.3 \%)\end{array}$ & $\begin{array}{l}1.35 \\
(27.3 \% / 20.2 \%)\end{array}$ & & \\
\hline 2400 & $\begin{array}{l}1.38 \\
(91.7 \% / 66.6 \%)\end{array}$ & $\begin{array}{l}1.42 \\
(30.6 \% / 21.5 \%)\end{array}$ & $\begin{array}{l}1.46 \\
(18.8 \% / 12.9 \%)\end{array}$ & \\
\hline 3200 & & $\begin{array}{l}1.49 \\
(41.0 \% / 27.5 \%)\end{array}$ & $\begin{array}{l}1.70 \\
(24.8 \% / 14.6 \%)\end{array}$ & \\
\hline 4800 & & $\begin{array}{l}1.58 \\
(60.5 \% / 38.4 \%)\end{array}$ & $\begin{array}{l}1.82 \\
(35.6 \% / 19.6 \%)\end{array}$ & $\begin{array}{l}1.77 \\
(27.1 \% / 15.3 \%)\end{array}$ \\
\hline 8000 & & $\begin{array}{l}1.29 \\
(78.6 \% / 60.7 \%)\end{array}$ & $\begin{array}{l}1.71 \\
(53.6 \% / 31.3 \%)\end{array}$ & $\begin{array}{l}1.94 \\
(41.6 \% / 21.5 \%)\end{array}$ \\
\hline 9600 & & & & $\begin{array}{l}1.93 \\
(47.3 \% / 24.5 \%)\end{array}$ \\
\hline
\end{tabular}




\section{Summary}

Using the PRETEX ${ }^{\circledR}$ process roughness parameters of skin pass rolls can be alter within wide limits (see Fig. 1 and 2). Roll surfaces can be adjusted so that they have the same average roughness $\left(\mathrm{R}_{\mathrm{a}} / \mathrm{S}_{\mathrm{a}}\right)$ and peak count $\left(\mathrm{R}_{\mathrm{Pc}}\right)$ values but different coverage of PRETEX ${ }^{\circledR}$ chromium calottes. Through this open and closed work-roll structures are accessible (see Fig. 2).

Roughness values of steel sheets and roll surfaces can be optically determined using confocal microscopy measurements. In the series of high manganese HSD $^{\circledR}$ steels the roughness transfer from work-roll to steel sheet surfaces decreases with increasing material yield strength. The roughness transfer is significantly influenced by the work-roll texture. Open structured work-rolls transfer a higher ratio of their roughness to steel sheet surfaces compared to closed structured workrolls. Increases of roughness transfers up to $94 \%$ could be achieved.

\section{References}

[1] C. Bergenstof, P.Nielsen, Leisner, A.Horsewell: On texture formation of chromium electrodeposits., J. Appl. Electrochem., 28 (1998) 141-150

[2] Müll, K.: Die Prozess- und Verfahrenstechnik von TOPOCROM ${ }^{2}$. http://www.topocrom.com/content/pdf/Artikel_Verfahren_k_muell.pdf(18.11.2015)

[3] Ritterbach, B.: Qualitätsregelkreis zur Erzeugung definierter Feinblechrauheiten mit verschiedenen Texturierverfahren., Fortschrittsberichte VDI, Nr. 517 (1998)

[4] Zimnik, W., Ritterbach, B., Müll, K.: PRETEX - Ein neues Verfahren zur Erzeugung texturierter Feinblechoberflächen für höchste Ansprüche., Stahl und Eisen, 118 (1998) 75-80

[5] Kijima, Hideo: Influence of roll radius on roughness transfer in skin-pass rolling of steel strip., J. Mater. Process. Technol., 214 (2014) 1111- 1119

[6] Wentink, D.J., Matthews D., Appelman, N.M., Toose, E.M.: A generic model for surface texture development, wear and roughness transfer in skin pass rolling., Wear, 328-329 (2015) 167-176

[7] Kijima, Hideo: An experimental investigation on the influence of lubrication on roughness transfer in skin-pass rolling of steel strip., J. Mater. Process. Technol., 225 (2015) 1-8

[8] Kijima, Hideo, Bay, Niels: Skin-pass rolling I - Studies on roughness transfer and elongation under pure normal loading., Int. J. Mach. Tool. Man., 48 (2008) 1313- 1317

[9] Kijima, Hideo, Bay, Niels: Skin-pass rolling II-Studies of roughness transfer under combined normal and tangential loading., Int. J. Mach. Tool. Man., 48 (2008) 1308 - 1312

[10] Deutscher, O.: Methods for attaining particular roughness on cold rolled strip., Iron Steel Eng. 74 (1997), $35-40$

[11] Steinhoff, K., Bünten, R., Rasp, W., Kopp, R., Pawelski, O.: Development of a model for the simulation of the transfer of surface structure in the temper-rolling process. Steel Res. 66 (1995) $520-525$

[12] ISO 25178: Geometric Product Specifications (GPS) - Surface texture: areal

[13] Wilson, T.: Confocal microscopy, Academic Press Inc. (1990)

[14] Ballard, D. H.: Generalizing the Hough Transform to Detect Arbitrary Shapes, Pattern Recognition, 13 (1981) 111-122 